\title{
Biodiversity Conservation Potential of Forests and Trees On Farms In the Agricultural-Forest Mosaic Landscape of Catacamas, Honduras
}

\section{Marie Ange Ngo Bieng ( $\square$ marie-ange.ngo_bieng@cirad.fr )}

CIRAD, Université de Montpellier, UR Forêts \& Sociétés

\section{Diego Delgado-Rodríguez}

CATIE - Centro Agronómico Tropical de Investigación y Enseñanza

\section{Sergio Vilchez}

CATIE - Centro Agronómico Tropical de Investigación y Enseñanza

Arlene López-Sampson

CATIE - Centro Agronómico Tropical de Investigación y Enseñanza

\section{Edwin García}

CATIE - Centro Agronómico Tropical de Investigación y Enseñanza

\section{Norvin Sepúlveda}

CATIE - Centro Agronómico Tropical de Investigación y Enseñanza

\section{Eduardo Somarriba}

CATIE - Centro Agronómico Tropical de Investigación y Enseñanza

\section{Research Article}

Keywords: Secondary forests, agricultural landscapes, live fences, livestock systems, rare and common species, Hill numbers

Posted Date: January 3rd, 2022

DOI: https://doi.org/10.21203/rs.3.rs-1178804/v1

License: (c) (1) This work is licensed under a Creative Commons Attribution 4.0 International License. Read Full License 


\section{Abstract}

Biodiversity decline in the tropics requires the implementation of comprehensive landscape management where agricultural systems are necessarily an integral element of biodiversity conservation. This study evaluates the potential for biodiversity conservation within an intensive livestock-agricultural-forest mosaic landscape in Catacamas, Honduras. Tree sampling was performed in 448 plots set up within different forest and agricultural land uses: secondary forests, agroforestry coffee plantations, agriculture, pastures, live fences and riparian forest. All trees with a minimum diameter at breast height of $10 \mathrm{~cm}$ were identified and measured. We characterized their tree structure and diversity, and compared tree diversity between the different uses. The results indicate a high degree of tree species diversity: 375 species identified, belonging to 74 families among the 15,096 trees inventoried across 84.2 hectares, including many rare species ( $40 \%$ of the species registered three individuals or fewer). Biodiversity indices for agroforestry coffee were found equivalent to those for natural secondary forests in the Catacamas landscape. Combining biodiversity conservation and agricultural production is possible in humanpressured tropical landscapes through tree cover maintenance. Enrichment practices combining local producers and technical knowledge may improve tree diversity in agricultural landscapes by prioritizing a mix of forest and introduced tree species (rare and with multiple uses).

\section{Introduction}

Tropical forests, irreplaceable for their role in supporting terrestrial biodiversity conservation [1, 2], are extremely vulnerable to destruction and degradation. Since 1990, most of the deforestation has occurred in tropical regions [3]. Deforestation and degradation of tropical forest areas, and conversion of forest landscapes into agricultural landscapes, is correlated with the worldwide decline in biodiversity in forest landscapes [2]. Many tropical landscapes are subjected to intense human activity, with highly fragmented forests inserted in a larger agricultural matrix.

For example, in Central America, where this study took place, it is estimated that $80 \%$ of the region's original vegetation had become agriculture by the beginning of the twenty-first century [4]. A land use change study over the period 1961-2001 found that the region experienced an average annual rate of reduction in forest cover of $1.2 \%$, with almost half of the original coverage eliminated [5]. As in many tropical countries, deforestation in Central America has primarily been associated with subsistence agriculture and livestock systems [6]. Central America is, however, key for tropical and neotropical biodiversity worldwide. It is a narrow strip land of over half a million $\mathrm{km}^{2}$ between South and North America and is considered as one of the planet's biodiversity hotspots [7], as the region contains around $7 \%$ of the world's biodiversity. The huge diversity of this region is related to its diversity of forest ecosystems: tropical moist broadleaf forests, tropical dry broadleaf forests, tropical and subtropical coniferous forests, and the decline in its biodiversity is related to the decrease in its forest areas and the increase of its agricultural areas. 
Biodiversity decline related to the continuous decrease in forest areas requires the implementation of comprehensive landscape management, involving conservation that goes beyond the protection of small, fragmented, isolated or poorly protected natural forest areas [8]. Besides, strict protection of forest areas would not be sufficient, or even possible, to conserve biodiversity within the global context of land use changes and the growing demand for agricultural products $[9,10]$.

The agricultural matrix must urgently become an integral element of biodiversity-friendly landscapes, i.e. a force in conserving biodiversity and providing vital ecosystem services to local populations, ensuring livelihoods in degraded landscapes [11]. This is one of the strategic objectives of the Convention on Biological Diversity (https://www.cbd.int/), which specifically recommends going beyond the mere protection of natural ecosystems, and the ecological rehabilitation of those that are degraded. A necessary and complementary alternative is to include biodiversity conservation as a goal in managed ecosystems, and the implementation of biodiversity conservation units within agricultural-forest mosaic landscapes [4].

The need to manage and increase terrestrial biodiversity in agricultural land uses and landscapes in line with the objective of reducing worldwide biodiversity decline and threats to forests and to protected areas, is already recognized $[12,13]$. The potential for biodiversity conservation, connectivity and provision of ecosystem services in tropical agricultural landscapes has been the subject of various studies $[12,14$, 15]. Emphasis is placed on the conservation of tree biodiversity in these agricultural systems. Indeed, trees in an agricultural matrix represent an effective option for increasing biodiversity in agricultural landscapes. This implies management practices that involve a diversification of trees on farms, for instance in agroforestry and silvo-pastoralism. In fact, increasing tree cover in the agricultural landscape helps to conserve and restore biodiversity in general. Tree cover in such landscapes provides a diversity of habitats, food and facilitates the movement of fauna in the landscape [16]. Tree cover in such landscapes may also improve agricultural productivity [17]. Overall, tree cover is associated with multiple regulating services, including nutrient retention [18], erosion control [19], carbon sequestration [20], pollination [21], pest and weed control [22]. Moreover, tree products such as timber, firewood and fruit may provide farmers with significant additional income [23]. Besides agro-silvo-pastoral systems, different studies have also highlighted the importance of forest fragments and scattered trees for biodiversity conservation within agricultural landscapes $[4,11,13,24,25]$.

Within this context, our study was set up as part of the "Trees on Farms for Biodiversity" project (ToNF: https://treesonfarmsforbiodiversity.com/). The project sought to improve biodiversity conservation in agricultural landscapes. This was achieved by building knowledge about the importance of trees on farms from an ecological, social and economic perspective. The project aimed to help producers to improve their livelihoods while reducing their financial and environmental vulnerability.

The aim of the study was therefore to share knowledge on the potential for biodiversity conservation of forests and trees on farms in a human-pressured landscape, which has been little studied in the literature. The study was set up in Honduras, a Central American country with an area of over 11 million hectares, 
more than half considered forest (6 million hectares) [3]. In the last ten years, Honduras has lost 21,000 hectares of forest annually and its forest landscape integrity index, which measures the degree of modification of the forest due to human pressure, is one of the worst in the world. The intensification of livestock systems and shifting cultivation are considered the main causes of forest degradation and deforestation in the country.

In Honduras, the study specifically focused on the landscape of Catacamas, recognized as a landscape highly pressured by the implementation of intensive livestock systems. The Catacamas region is important for biodiversity conservation in the region because it borders on three protected areas that are a priority for biodiversity conservation at the regional level. These protected areas are the Río Plátano Biosphere Reserve, the Patuca National Park and the Tawahka Biosphere Reserve. Because of their connection to the Bosawas Biosphere Reserve in northeastern Nicaragua, the protected areas are part of an extensive regional network of protected forest areas that contribute to biological connectivity across Central America. They are therefore key areas for regional conservation initiatives, such as the Mesoamerican Biological Corridor and the "five great forests" of Mesoamerica (https://www.sica.int/noticias/alianza-cinco-grandes-bosques-de-mesoamerica-iniciativa-ambientalcentroamericana-lanzada-en-la-cop25_1_120718.html).

The aim of the study was to characterize tree diversity in different land uses in the Catacamas landscape and to assess the potential for biodiversity conservation. We tested the hypothesis that in pressured landscapes such as this, biodiversity conservation was equally provided by agro-silvo-pastoral systems and forest systems, at plot and at landscape scale. We therefore compared tree diversity in different forest and agricultural land uses within the agricultural-forest mosaic landscape of Catacamas in Honduras.

\section{Results}

\section{Characterization of tree structure and diversity in the Catacamas landscape}

In a study area of 84.24 hectares, 15,096 trees belonging to 375 species and 74 families were recorded (Table 3). The maximum expected species richness across the landscape (plus standard error) was 450 \pm 23 (Chao1) and $444 \pm 11$ (ACE).

Fabaceae represented $19 \%$ of the total species reported in the study, followed by lauraceae with just $5 \%$ of the total species. A total of 30 families were represented by a single species and 12 families by at least two species. The species Guazuma ulmifolia, Gliricidia sepium and Bursera simaruba represented $33 \%$ of the trees inventoried (1851, 1849 and 1229 trees respectively) and $40 \%$ of the species reported were represented by three trees or fewer. 
The highest percentage of trees was recorded in live fences (42\%), followed by forest fragments (18\%), and the lowest percentage of trees was recorded in agroforestry coffee plantations (3\%). The highest species richness was reported in forests fragments (193), followed by riparian forest (158) and live fences (154), while the lowest number of species was observed in agriculture (79) and in agroforestry coffee (65) (Table 1).

Among the total species in Catacamas, $40 \%$ were represented by three or fewer individuals, denoting a high rarity at the level of species in the landscape. Species recorded only once in the study (singletons, represented by only one individual) represented $22 \%$ of the total species ( 81 species). The land use with the highest percentage of rare species was agriculture (68\%), followed by agroforestry coffee $(57 \%)$ and continuous secondary forest (56\%). Three land uses showed the highest percentages of species represented by only one individual: agricultural land (37\%), agroforestry coffee (37\%) and pasture (31\%). Live fences, on the other hand, showed the smallest percentage of unique species (18\%).

Table 1

Number of species found by land use in Catacamas. The different land uses are secondary forest (SF), secondary forest fragment (SFF), agroforestry coffee (AFC), agriculture (AGRI) and pastures (PAST), live fences (LF) and riparian forest (RF).

\begin{tabular}{|llllllll|}
\hline $\begin{array}{l}\text { Land } \\
\text { uses }\end{array}$ & Species & Individuals & $\begin{array}{l}\text { Singleton } \\
\text { species }\end{array}$ & $\begin{array}{l}\text { Doubleton } \\
\text { species }\end{array}$ & $\begin{array}{l}\text { Tripleton } \\
\text { species }\end{array}$ & $\begin{array}{l}\text { Plot } \\
\text { area }\end{array}$ & $\begin{array}{l}\text { Total area } \\
\text { (ha) }\end{array}$ \\
\hline LF & 154 & $\begin{array}{l}6285 \\
(42 \%)\end{array}$ & 29 & 22 & 15 & 0.02 & 7.24 \\
\hline RF & 158 & $\begin{array}{l}2517 \\
(17 \%)\end{array}$ & 35 & 17 & 16 & 0.25 & 10.5 \\
\hline SFF & 193 & $\begin{array}{l}2778 \\
(18 \%)\end{array}$ & 53 & 20 & 7 & 0.5 & 12 \\
\hline PAST & 94 & $1301(9 \%)$ & 29 & 13 & 2 & 1 & 28 \\
\hline AGRI & 70 & $414(3 \%)$ & 26 & 16 & 6 & 1 & 17 \\
\hline SF & 111 & $1380(9 \%)$ & 34 & 16 & 12 & 0.5 & 5.5 \\
\hline AFC & 65 & $421(3 \%)$ & 24 & 9 & 4 & 1 & 4 \\
\hline Total & 375 & 15,096 & 81 & 42 & 28 & & 84.24 \\
\hline
\end{tabular}

The accumulation curve for the whole tree community ( ${ }^{0} \mathrm{D}$, with 375 effective species), indicates a high diversity of species with low abundances. Therefore, registration of many trees is required to reach the maximum observed effective species (Fig. 1). The number of effective common species ( ${ }^{1} \mathrm{D}, 60$ species) peaks with less than $15 \%$ of the recorded trees. The same behavior occurs with the dominant effective species ( ${ }^{2} D, 22$ species).

\section{Distribution of species abundance by land use}


Forests fragments, riparian forests and living fences presented the greatest range of species (according to the length of their rank-abundance curves, Fig. 2) and the greatest abundance of species. They also showed a high level of dominance by a few species (indicated by the abrupt decline of curves near the Yaxis, Fig. 2). By contrast, the abundance of species in agriculture and agroforestry coffee showed a more equitable distribution (there is no abrupt decline). Pastures and forests show an intermediate behavior.

Three species were particularly abundant in Catacamas, especially in agricultural land uses, live fences and pasture: Gliricidia sepium, Guazuma ulmifolia and Bursera simaruba (Table 4). G. sepium was the most common in live fences $(24.9 \%$ of total trees) and in agriculture $(21.7 \%)$, while G. ulmifolia was the most common in pasture (17.8\%) and was also found dominant in the natural forests, riparian forest $(23.7 \%)$ and secondary forest fragments (6.1\%). In secondary forest the most common species was Quercus peduncularis and in agroforestry coffee plantations, it was Khaya senegalensis (Table 2). Fig. S1 in the Supplementary Information lists the 60 most common species in the landscape, and the distribution of their abundance by land use. 
Table 2

List of the five most abundant species for each land use (species that stand out in the rank-dominance curves). The different land uses are secondary forest (SF), secondary forest fragment (SFF), agroforestry coffee (AFC), agriculture (AGRI) and pastures (PAST), live fences (LF) and riparian forest (RF).

\begin{tabular}{|c|c|c|c|c|c|}
\hline AGRI & & LF & & PAST & \\
\hline Species & Ind (\%) & species & Ind (\%) & species & Ind (\%) \\
\hline Gliricidia sepium & $\begin{array}{l}90 \\
(21.74)\end{array}$ & Gliricidia sepium & $\begin{array}{l}1563 \\
(24.87)\end{array}$ & $\begin{array}{l}\text { Guazuma } \\
\text { ulmifolia }\end{array}$ & $\begin{array}{l}232 \\
(17.83)\end{array}$ \\
\hline Guazuma ulmifolia & $\begin{array}{l}61 \\
(14.73)\end{array}$ & Bursera simaruba & $\begin{array}{l}956 \\
(15.21)\end{array}$ & $\begin{array}{l}\text { Gliricidia } \\
\text { sepium }\end{array}$ & $\begin{array}{l}121 \\
(9.3)\end{array}$ \\
\hline Cecropia peltata & $\begin{array}{l}23 \\
(5.56)\end{array}$ & Guazuma ulmifolia & $\begin{array}{l}781 \\
(12.43)\end{array}$ & $\begin{array}{l}\text { Bursera } \\
\text { simaruba }\end{array}$ & $\begin{array}{l}120 \\
(9.22)\end{array}$ \\
\hline Bursera simaruba & $\begin{array}{l}21 \\
(5.07)\end{array}$ & Jatropha curcas & $\begin{array}{l}427 \\
(6.79)\end{array}$ & $\begin{array}{l}\text { Mimosa } \\
\text { tenuiflora }\end{array}$ & $\begin{array}{l}90 \\
(6.92)\end{array}$ \\
\hline Tabebuia rosea & $\begin{array}{l}21 \\
(5.07)\end{array}$ & Mimosa tenuiflora & $\begin{array}{l}419 \\
(6.67)\end{array}$ & $\begin{array}{l}\text { Byrsonima } \\
\text { crassifolia }\end{array}$ & $69(5.3)$ \\
\hline AFC & & SFF & & SF & \\
\hline Khaya senegalensis & $\begin{array}{l}79 \\
(18.76)\end{array}$ & Guazuma ulmifolia & $\begin{array}{l}169 \\
(6.08)\end{array}$ & $\begin{array}{l}\text { Quercus } \\
\text { peduncularis }\end{array}$ & $\begin{array}{l}211 \\
(15.29)\end{array}$ \\
\hline Ilex tectonica & $24(5.7)$ & $\begin{array}{l}\text { Byrsonima } \\
\text { crassifolia }\end{array}$ & $\begin{array}{l}159 \\
(5.72)\end{array}$ & $\begin{array}{l}\text { Quercus } \\
\text { oleoides }\end{array}$ & $\begin{array}{l}180 \\
(13.04)\end{array}$ \\
\hline Dialium guianense & $\begin{array}{l}20 \\
(4.75)\end{array}$ & Curatella americana & $\begin{array}{l}147 \\
(5.29)\end{array}$ & $\begin{array}{l}\text { Curatella } \\
\text { americana }\end{array}$ & $\begin{array}{l}108 \\
(7.83)\end{array}$ \\
\hline $\begin{array}{l}\text { Brosimum } \\
\text { alicastrum }\end{array}$ & $\begin{array}{l}18 \\
(4.28)\end{array}$ & Aosa grandis & $\begin{array}{l}123 \\
(4.43)\end{array}$ & Pinus caribaea & $\begin{array}{l}100 \\
(7.25)\end{array}$ \\
\hline $\begin{array}{l}\text { Lonchocarpus } \\
\text { hondurensis }\end{array}$ & $\begin{array}{l}18 \\
(4.28)\end{array}$ & $\begin{array}{l}\text { Lonchocarpus } \\
\text { hondurensis }\end{array}$ & $\begin{array}{l}117 \\
(4.21)\end{array}$ & $\begin{array}{l}\text { Byrsonima } \\
\text { crassifolia }\end{array}$ & $\begin{array}{l}89 \\
(6.45)\end{array}$ \\
\hline \multicolumn{6}{|l|}{ RF } \\
\hline Guazuma ulmifolia & $\begin{array}{l}596 \\
(23.68)\end{array}$ & & & & \\
\hline Spondias mombin & $\begin{array}{l}124 \\
(4.93)\end{array}$ & & & & \\
\hline Cecropia peltata & $88(3.5)$ & & & & \\
\hline Inga vera & $\begin{array}{l}82 \\
(3.26)\end{array}$ & & & & \\
\hline Tabebuia rosea & $\begin{array}{l}76 \\
(3.02)\end{array}$ & & & & \\
\hline
\end{tabular}




\section{Distribution by diameter class of species number, tree density and basal area per hectare}

The greatest species richness and tree density is found in the diameter classes smaller than $30 \mathrm{~cm}$. By contrast, the largest basal areas are in the diameter class greater than $70 \mathrm{~cm}$ (Fig. 3). Tree distribution in diametric classes for all the study land uses had an inverted curve shape, indicating high tree densities in smaller diametric classes, and low tree densities in larger diametric classes.

Live fences had the highest tree density and total basal area, but the lowest species richness. Together with agroforestry coffee, live fences stand out from the other agricultural uses because of the high density of trees in lower and higher diametric classes. Agroforestry coffee, secondary forests, secondary forest fragments and riparian forest showed the highest species richness, while PAST and AGRI showed intermediate values. Forests (secondary, secondary fragments and riparian) had higher tree densities than pasture, agriculture and agroforestry coffee systems. The lowest basal area was recorded in pasture and agriculture.

\section{Diversity in different types of land use}

\section{Species accumulation curves by land use}

Secondary forest fragments and riparian forest had the highest number of total effective species $\left({ }^{0} \mathrm{D}\right)$, followed by secondary forest, while there was no significant difference between the other land uses. (Fig. 4). The highest number of effective common species ( $\left.{ }^{1} \mathrm{D}\right)$ were found in secondary forest fragments, followed by secondary forest and agroforestry coffee, while live fences showed the lowest number of effective common species. Accounting for dominant species diversity, secondary forest fragments represented the land use with the highest number of effective dominant species $\left({ }^{2} D\right)$, while there was no significant difference between the other land uses.

\section{Comparison of alpha diversity between land uses}

We found significant differences in average diversity per plot (alpha diversity) in the three estimated Hill numbers. The average effective total number of species $\left({ }^{0} \mathrm{D}\right)$ was higher in agroforestry coffee, followed by secondary forest fragments. Live fences, pasture and agriculture showed the lowest average values of ${ }^{0} \mathrm{D}$. For the effective average number of common species $\left({ }^{1} \mathrm{D}\right)$, agroforestry coffee showed greater diversity than the other uses, and live fences and pasture the lowest values. Forests (secondary, secondary fragments and riparian) and agriculture did not differ from each other in the average value of ${ }^{1} \mathrm{D}$. The diversity of dominant species $\left({ }^{2} \mathrm{D}\right)$ was higher in agriculture than in other land uses. Live fences and pasture presented the lowest diversity value for dominant species (Fig. 5).

\section{Comparisons of beta diversity between land uses in the study landscape}


Beta diversity, as a measure of dissimilarity, presented differences between land uses (Fig. 6). The dissimilarity of the total effective number of species $\left({ }^{0} \mathrm{D}\right)$ was greater in secondary forest, secondary forest fragments and riparian forests than in live fences. For common species ( $\left.{ }^{1} D\right)$, all forests and agroforestry coffee showed greater dissimilarity than live fences. Furthermore, the dissimilarity of the effective number of dominant species $\left({ }^{2} \mathrm{D}\right)$ was greater in agriculture, secondary forest fragments and riparian forest than in live fences. Forests, agriculture, pasture and agroforestry coffee did not show any difference in the dissimilarity of dominant species.

\section{Discussion}

Although the Catacamas landscape is dominated by extensive livestock production systems, our results indicate that the land uses matrix within the landscape displayed a high diversity of tree species (375 species in the 84.2 ha evaluated). The assessed tree species diversity is characterized by many rare species ( $40 \%$ of the species listed registered three individuals or fewer). Tree diversity is also characterized by very few dominant species: $5 \%$ of the total number of species accounted for $66 \%$ of all inventoried trees. The highest tree density and diversity are found in diameter classes with a diameter at breast height (DBH) of 10 to $20 \mathrm{~cm}$ (52\% of total records), indicating a high diversity of young individuals.

In the Catacamas landscape, agricultural land uses are important for landscape biodiversity. For some agricultural land uses such as agroforestry coffee plantations, the biodiversity indices computed were equivalent to the natural forest land uses assessed in the landscape. However, tree diversity and structure differ according to the various agricultural land uses examined in the study.

Live fences are structurally the land use that displays the greatest tree density and basal area. Of the total number of trees, $42 \%$ can be found in live fences (about 868 individuals ha- ${ }^{1}$ ). Tree density in live fences is even higher than in natural forests (231-251 trees $\left.\mathrm{ha}^{-1}\right)$. The other cropping land uses have a low tree density: agroforestry coffee plantations ( $3 \%$ of the evaluated landscape) display about 16 trees ha-1, agriculture (3\%) about 4.1 tree ha ${ }^{-1}$, and pastures (9\%) about 3.4 trees $\mathrm{ha}^{-1}$.

Live fences, agriculture and pasture have a similar tree composition when accounting for the most abundant species. As found in another studies, these agricultural land uses present an effective total number of tree species $\left({ }^{0} \mathrm{D}\right)$ that is lower than in the natural forests within the same landscape. All these agricultural land uses differ from forests because the density of trees is concentrated in very few species. This is particularly notable in live fences, where $66 \%$ of individuals belong to just five species. These dominant species are heliophytes, fast growing and common in the agricultural landscapes of the region, mainly Gliricidia sepium, Bursera simaruba, Guazuma ulmifolia, Jatropha curcas, Cecropia peltata, Tabebuia rosea, Byrsonima crassifolia and Mimosa tenuiflora [26].

The specific abundance of multipurpose species (e.g. for firewood, fodder and poles) is the result of tree management on agricultural farms in Catacamas [27]. Excluding Cecropia peltata and Byrsonima crassifolia, the tree species in agricultural uses are frequently planted by farmers. These trees are 
selected for their tolerance to dry climate and degraded soils, usefulness for shade management (high regrowth and survival following successive pruning) and production of fodder for livestock [26].

Guazuma ulmifolia is the dominant species in Catacamas. It is one of the five most abundant species. In our study landscapes, it is found in almost all land uses, except agroforestry coffee and riparian forest. It is an abundant tree species in many secondary forests and pastures in the livestock landscapes of the Central America dry zone. Its characteristics include fast regrowth and early fruiting, at 6-10 years of age. Its seeds have a great capacity to colonize degraded livestock land that is unfavorable for many tree species and its fruit is consumed by livestock, which becomes an effective means of seed dispersal. Guazuma ulmifolia, like other species managed by farmers in the region, is therefore highly valued for the ecosystem services it provides: timber, shade and fodder for livestock. This is the reason its regeneration is promoted on livestock farms. Other species such as Byrsonima crassifolia and Tabebuia rosea, are also found in secondary forests and successfully regenerate in pastures [26].

Finally, among the agricultural uses in Catacamas, agroforestry coffee plantations stand out for their high species richness, which is greater than tree species richness in other agricultural land uses, and similar to the tree species richness of secondary forest. Agroforestry coffee plantations maintain a high cover of remnant forest trees, compared to other types of agroforestry systems where trees are planted. Therefore its tree species richness is high, as well as the richness of other taxonomic groups that are related to trees species, such as bats and birds [27].

Of the five most abundant species in agroforestry coffee plantations in Catacamas, only L. hondurensis is recorded among the main species in secondary forest fragments. Almost all the species in agroforestry coffee plantations are native and frequently found in natural forests. Only African mahogany $(K$. senegalensis, Meliaceae), a large multipurpose exotic tree, was introduced in agroforestry coffee. It is of great commercial value for wood, fodder and medicine for livestock and humans [28]. African mahogany was introduced from Africa to Central America in the early 1990s in forest plantations.

Studies in Central America show how certain agricultural practices contribute to conserving and/or restoring biodiversity in agricultural landscapes while improving the well-being of rural families by increasing food production and providing firewood and timber, among other products $[29,30]$. A number of studies such as the research carried out by Sánchez et al. [31] have found, like our study, significant tree diversity in livestock landscapes in Central America. Increasing tree cover on farms is a key practice in providing complementary habitat, resources and landscape connectivity for a significant group of natural wildlife [27, 32]. Silvo-agricultural landscapes function as a buffer zone for the remaining natural areas, contributing to the maintenance of important ecosystem services at the regional level [33], as is the case with Catacamas landscape examined in our study.

Forest land uses play a key role in the overall diversity of the Catacamas landscape. In this study, continuous and fragmented secondary forest, as well riparian forests, were the land uses that presented the highest effective total number of species $\left({ }^{0} \mathrm{D}\right)$ and common species $\left({ }^{1} \mathrm{D}\right)$. 
Our results confirm the importance of forest systems for biodiversity conservation in human-pressured tropical landscapes. The value of goods and services provided by secondary and fragmented forests is increasingly recognized [34]. Although not considered equal to mature forests in terms of biodiversity conservation [2], they may experience a rapid recovery in species richness and associated ecosystem services [34].

However, the levels of tree diversity found in the natural forests in Catacamas indicate that these systems are degraded or in immature stages of secondary succession. Compared to other secondary forests in the region, the forests in Catacamas have very few species per area (per 100 individuals, 23 species in secondary forest, 22 species in secondary fragmented forest and 19 in riparian forest). The biodiversity values described by Rozendaal et al [34] for neotropical secondary forests are, on average, 11 species per 25 individuals with a DBH of at least $10 \mathrm{~cm}$.

In many productive tropical landscapes similar to Catacamas, a high proportion of the forests are fragmented. These fragments tend to be small, isolated and strongly influenced by adjacent agricultural uses, which affects the connectivity and transit of potential seed dispersers. Intensive farming and the presence of livestock can significantly affect natural regeneration in these forest systems $[35,36]$. In this context, the conservation of tree diversity in surrounding agricultural land uses is crucial and can contribute to strengthening the diversity of forests and landscape in general [16], especially in landscapes such as Catacamas, under intense human activity and highly fragmented.

\section{Implications for tree diversity management in Catacamas and in human-pressured landscapes}

Our results highlight the potential of tree diversity in agricultural landscape as Catacamas, and the valuable contribution of agricultural systems. These results are important for a geographically strategic livestock landscape such as this, since it connects and serves as a buffer for surrounding areas of importance for biodiversity conservation in Mesoamerica, such as the Rio Plátano Biosphere Reserve, the Patuca National Park and the Tawahka Biosphere Reserve.

The trees in the different land uses in Catacamas, besides having an intrinsic value as part of the biodiversity of the landscape, are key for their contribution in terms of fauna habitat and resources, and for the provision of key ecosystem services. The selection and management of trees outside forests in livestock landscapes provide fodder, firewood, fruit and timber. These trees have an ecological, social and economic importance that must be recognized, valued and managed. The present study establishes the knowledge bases for the implementation of biodiversity management actions in the landscape.

The role of agricultural systems in the biodiversity of the Catacamas landscapes is relevant, especially in the case of agroforestry coffee plantations. Despite their small area, they contribute greatly to the diversity of the landscape, particularly because of the total number of species and the number of common species that they contain. Management practices applied to these diversified farming systems, such as the introduction of local tree forest species, may be useful for other less diverse agricultural land uses in the landscape, such as live fences and pasture systems. For land uses such as live fences, 
agriculture and pastures, which are of low alpha diversity and contribute little to the beta diversity of the landscape, we recommend enrichment practices to increase the number of common species and the total number of species, prioritizing a mix between primary forest species, which are very rare in this landscape, and selected multiple-use species that are useful for farmers.

The application of local producer knowledge, combined with technical knowledge, has proved successful in improving ecosystem services that promote trees, such as agro-silvo-pastoral systems[37]. We recommend meetings with producers of different land uses in order to share experiences the management of trees on farms, tree species use and diversification. The promotion of demonstration sites of good farm management and field schools has shown great value as a methodological approach. This may allow farmers to identify the main problems affecting their production systems and, with their own resources, find biodiversity-friendly solutions that are relevant to their biophysical and socioeconomic conditions.

As in many tropical landscapes, the natural forests of Catacamas are secondary and highly degraded forests. This is highlighted by their species composition and low levels of diversity. It may be useful to increase their ecological resilience and economic value by applying active restoration [35, 38]. In Catacamas, the restoration of forests could consist of enrichment with primary forest species along with the promotion of regeneration and growth of tree species with multiple uses. Farmers' knowledge of tree species may be useful in this kind of active restoration plan.

\section{Material And Methods}

\section{Study area}

The study was carried out in the Catacamas sentinel landscape, a pilot site of the TonF project. The Sentinel Landscapes initiative was created in 2012 by the CGIAR Research Program on Forests, Trees and Agroforestry (FTA). The objective of the initiative is to conduct long-term research using standardized methodologies on the temporal and spatial dynamics of land use, trees and forests in selected territories (https://www1.cifor.org/sentinel-landscapes/home.html). The initiative includes eight sites around the world, representing very different biophysical and socioeconomic contexts, and ends its second and final phase in December 2021. The Catacamas sentinel landscape is located in the municipality of Catacamas, department of Olancho, Honduras. Catacamas has approximately 133,896 inhabitants and is known for its livestock sector, dairy production, meat and basic grains. The livestock sector is the most productive in the municipality, representing a gross value of more than USD 100 million annually.

Livestock production systems are extensive, with low productivity, and have a high impact on natural resources, for example local natural forests. Catacamas is one of the municipalities with the highest deforestation rate in the country, most of which is attributed to implementation of livestock systems.

Within the Catacamas sentinel landscape, the study was conducted specifically in the Guayape Valley. It is an area with vegetation characteristic of tropical dry forest and, to a lesser extent, subtropical wet 
forest. Forests are mainly secondary in the Catamas landscape. The Guayape valley is at an average altitude of $450 \mathrm{~m}$ above sea level, with an average annual temperature of $24.7^{\circ} \mathrm{C}$ and an annual rainfall of $1235 \mathrm{~mm}$. The north of the study area is connected to the Piedra Blanca Mountain, which is part of the Sierra de Agalta National Park. This park is of great importance for the conservation of biodiversity due to its richness in plant and animal species, including felines and quetzales. The park has an area of 518 $\mathrm{km}^{2}$ and is part of the Sierra de Sulaco, which reaches a maximum altitude of $2590 \mathrm{~m}$. The vegetation of the Sierra de Sulaco is characterized by forests of Pinus-Quercus between 700 and $1500 \mathrm{~m}$ above sea level, and above by broadleaf cloud forest. In this agricultural-forest landscape, rustic agroforestry coffee plantations (coffee plantations established under thinned forest) and basic grain cropping systems are frequent [39].

\section{Sampling design}

In the study landscape, an area of $25 \mathrm{~km}$ x $25 \mathrm{~km}(625 \mathrm{~km} 2)$ was delineated and represented an agroecological gradient, following the methodology of the sentinel landscape initiative [40]. This area was further divided into quadrats of $5 \mathrm{~km} \times 5 \mathrm{~km}(25 \mathrm{~km} 2)$. Ten quadrats were selected, and in each one, vegetation sampling plots were located according to different land uses (Fig. 7). The aim was to have at least four different land uses in each quadrat (Table 3). The land uses considered were: i) secondary forest (SF), defined as secondary natural woody vegetation of more than 100 ha in area; ii) secondary forest fragment (SFF), corresponding to secondary forest areas of between 1-100 ha; iii); agroforestry coffee plantations (AFC); iv) agriculture (AGRI), consisting mainly of basic grains (maize, beans) and v) pastures (PAST). Plots were also located in live fences (LF) and riparian forest (RF) in the ten selected quadrats. 
Table 3

Number of plots set up per quadrat in each land use. The different land uses are secondary forest (SF), secondary forest fragment (SFF), agroforestry coffee (AFC), agriculture (AGRI) and pastures (PAST), live fences (LF) and riparian forest (RF).

\begin{tabular}{|llllllllll|}
\hline $\begin{array}{l}\text { ID } \\
\text { quadrat }\end{array}$ & AGRI & RF & SF & SFF & LF & PAST & AFC & $\begin{array}{l}\text { Number of land } \\
\text { uses }\end{array}$ & $\begin{array}{l}\text { Number of } \\
\text { plots }\end{array}$ \\
\hline 3 & 6 & 6 & & 2 & 50 & 3 & & 5 & 67 \\
\hline 5 & & 6 & 1 & 2 & 29 & 3 & & 5 & 41 \\
\hline 6 & 1 & 1 & 4 & 10 & 3 & 1 & 3 & 7 & 23 \\
\hline 9 & 4 & 8 & & 1 & 51 & 3 & 1 & 6 & 68 \\
\hline 11 & 1 & 4 & & 2 & 28 & 1 & & 5 & 36 \\
\hline 15 & & 3 & 1 & 1 & 35 & 5 & & 5 & 45 \\
\hline 18 & 2 & 3 & & & 62 & 4 & & 4 & 61 \\
\hline 24 & 1 & 2 & & 3 & 24 & 2 & 4 & 5 & 44 \\
\hline
\end{tabular}

\section{Vegetation sampling}

Tree sampling was performed within each plot of the various quadrats, according to each land use category (Table 4), following the protocols of Harrison et al [40]. For the agricultural and pasture land uses, a circular plot of 1.0 ha (with a radius of $56.4 \mathrm{~m}$ ) was set up. For secondary forest and secondary forest fragments, plots of 0.5 ha (radius $39.9 \mathrm{~m}$ ) were set up because these land uses had high tree densities. For riparian forest, a rectangular plot of 0.25 ha was delineated. Since riparian forest varied in width in the different plots, the dimensions (width and length) varied for each sampling plot, but their area was always kept to 0.25 ha. For live fences, each sampling plot was a segment that was $100 \mathrm{~m}$ long and $2 \mathrm{~m}$ wide. 
Table 4

Number of quadrats, plots and trees in each land use. Plot area and total sampled area are displayed. The different land uses are secondary forest (SF), secondary forest fragment (SFF), agroforestry coffee plantations (AFC), agriculture (AGRI) and pastures (PAST), live fences (LF) and riparian forest (RF).

\begin{tabular}{|llllll|}
\hline $\begin{array}{l}\text { Land } \\
\text { uses }\end{array}$ & $\begin{array}{l}\text { Number of } \\
\text { quadrats }\end{array}$ & $\begin{array}{l}\text { Number of } \\
\text { plots }\end{array}$ & $\begin{array}{l}\text { Number of trees } \\
\text { sampled }\end{array}$ & $\begin{array}{l}\text { Plot area } \\
\text { (ha) }\end{array}$ & $\begin{array}{l}\text { Total sample area } \\
\text { (ha) }\end{array}$ \\
\hline LF & 10 & 362 & 11048 & 0.02 & 7.24 \\
\hline RF & 10 & 42 & 2549 & 0.25 & 10.5 \\
\hline SFF & 9 & 24 & 2784 & 0.5 & 12 \\
\hline PAST & 10 & 28 & 2129 & 1 & 28 \\
\hline AGRI & 7 & 17 & 605 & 1 & 17 \\
\hline SF & 4 & 11 & 1383 & 0.5 & 5.5 \\
\hline AFC & 2 & 4 & 415 & 1 & 4 \\
\hline
\end{tabular}

In each plot, we monitored all the trees with a minimum diameter at breast height (DBH) of $10 \mathrm{~cm}$. For each tree, we recorded its species and DBH (around $1.3 \mathrm{~m}$ from the soil). For multiple-stem trees, the DBH of each stem with at least the minimum $10 \mathrm{~cm}$ was recorded. For trees with broken stems, the DBH and height to the breaking point were measured. Verification of botanical identification made in the field was carried out at family level using the Missouri Botanical Gardens platform (https://www.missouribotanicalgarden.org/) and at the species level using the Taxonomic Name Resolution Service (http://tnrs.iplantcollaborative.org/).

\section{Data analysis}

To characterize tree structure and diversity in the Catacamas landscape, we performed an analysis of diameter distribution by abundance class and total basal area. We also analyzed the total diversity of the landscape.

In order to understand the distribution and structure of tree diversity in the Catacamas landscape, we generated distributions per diameter class per hectare for each land use, for species density, tree density and basal area. The expected species density per hectare in each diameter class was estimated by the rarefaction method [41]. We used the average number of trees per hectare for each diameter class as the number of individuals for the rarefaction (sample size) (Supplementary Information, Table S1).

To visualize the distribution of species abundance, we built rank-abundance curves for each of the land uses. These curves are used to visualize the relative abundance, richness and uniformity of species, in order to identify rare and dominant species [42]. In order to produce the curves, we adjusted different models that assume hypotheses for the distribution of resources and therefore the community structure: steeper curves assume that very few species are sharing the resource, while smoother curves assume that the resource is evenly distributed (Supplementary Information, Table S2). 
For the entire landscape, we built species accumulation curves based on Hill numbers of order $q\left({ }^{9} D\right)$ from individuals using the interpolation and extrapolation method [43]. The maximum number of individuals to extrapolate was 15,000 , which corresponded to the total number of individuals inventoried in the study landscape. Hill numbers represent the actual number of species [44] that compose the community. The curves were created for the order numbers $0\left({ }^{0} \mathrm{D}\right)$, which is interpreted as the effective number of total species (species richness), with a greater weight for rare species. Order $1\left({ }^{1} D\right)$ is the effective number of common species and counts species in proportion to their abundance. Order $2\left({ }^{2} \mathrm{D}\right)$ is the effective number of dominant species, which discards all species which occur with low frequency and accounts for the most predominant. We also calculated the maximum expected richness in the landscape using abundance-based coverage estimators (ACE) and Chao1 [45].

In order to assess the potential for tree biodiversity conservation of the different land uses within the Catacamas landscape, we made comparisons of plot-level diversity.

To compare the land uses that we evaluated according to their maximum accumulated diversity, we constructed species accumulation curves based on the Hill numbers of order $q\left({ }^{0} D,{ }^{1} D\right.$ and $\left.{ }^{2} D\right)$ from individuals using the interpolation and extrapolation method for each land use. The curves were constructed for 2000 trees corresponding to the average of the total number of individuals recorded for the seven land uses evaluated.

We estimated the average diversity per plot (alpha diversity) based on the Hill numbers of order $q=0, q=1$ and $q=2$ [43]. Since sampling efforts were different between land uses, we standardized estimates of alpha diversity per plot through the interpolation-extrapolation method [43], using 100 individuals (the median of the records for all plots). Subsequently, we performed variance analysis between land uses for each diversity descriptor $(\mathrm{qDa})$, adjusting generalized linear models with negative binomial distribution [46]. Where we found differences, a means comparison test was performed.

The total diversity of the Catacamas landscape is a product of the diversity of each land use that is part of it. Therefore, in order to quantify the contribution of each land use to the total landscape diversity, we estimated the actual number of species diversity contributing to total diversity for each sampling plot as a measure of beta diversity ( $\left.{ }^{\mathrm{G} D} \beta\right)$, expressed as $1 /\left({ }^{\mathrm{q}} \mathrm{D} \gamma /{ }^{\mathrm{q}} \mathrm{Da}\right)$ and interpreted as the proportion of total diversity that, on average, a plot does not share with other plots (dissimilarity). The greater the difference (dissimilarity) with respect to total diversity, the greater the contribution each land use made to the total diversity of the landscape. As in the case of alpha diversity, we performed comparisons between land uses for each beta diversity descriptor (qDB), adjusting generalized linear models with negative binomial distribution [46]. If differences were found, we carried out means comparison tests.

The analyses were performed using $\mathrm{R}$ version 4.0.1 [47]. Rarefaction analyses were made with the function rarefi of the vegan package [48], extrapolation and interpolation analyses with the iNEXT package[49], and glm with the MASS package [50], using the function glm.nb. that allows adjustment of 
generalized linear models with negative binomial distribution. All graphics were built using the ggplot2 [51] and gridExtra packages [52].

All methods were carried out in accordance with relevant guidelines and regulations.

\section{Declarations}

\section{Data Availability}

The datasets generated during and/or analysed during the current study are available from the corresponding author on reasonable request.

\section{Acknowledgements}

This study was funded by the CGIAR Research Program on Forests, Trees and Agroforestry (CRP-FTA). This research was carried out by CATIE as part of the CRP-FTA. The aim of the program is to improve the management and use of forests, agroforestry and tree genetic resources across the landscape, from forests to plantations. CATIE is part of the CRP-FTA program in partnership with Bioversity, CIRAD, CIFOR, CIAT, INBAR, Tropenbos and ICRAF.

We would like to thank all the financial partners who supported this research through their contributions to the CGIAR Fund. To view a list of donors to the Fund, visit: https://www.cgiar.org/funders/.

We would finally like to thank our English language scientific editor, Kate Roberts, for her thorough review of our manuscript.

\section{Author contributions}

E.S., A.L-S., E.G. and N.S. designed the experiments. A.L-S., E.G. and N.S. developed the field experiments and collected the information. S.V., D.D.-R. and M.A.N.B. analyzed the data, commented the results and supervised the writing process. M.A.N.B., D.D.-R., S.V., A.L-S. and E.S. contributed to the writing of the manuscript. All the authors revised the different versions.

\section{Competing interests}

The author(s) declare no competing interests.

\section{References}

1. Pimm, S. L. \& Raven, P. Extinction by numbers. Nature 403, 843-845 (2000).

2. Gibson, L. et al. Primary forests are irreplaceable for sustaining tropical biodiversity. Nature 478, 378381 (2011). 
3. FAO. Global Forest Resources Assessment 2020 (FAO, 2020).

4. Harvey, C. A. et al. Integrating agricultural landscapes with biodiversity conservation in the Mesoamerican hotspot. Conserv. Biol. 22(1), 8-15 (2008).

5. Brouwer, F. \& McCarl, B. A. Agriculture and Climate Beyond 2015: A New Perspective on Future Land Use Patterns. https://doi.org/10.1007/1-4020-4368-6 (Springer, 2006).

6. Redo, D. J., Grau, H. R., Aide, T. M., \& Clark, M. L. Asymmetric forest transition driven by the interaction of socioeconomic development and environmental heterogeneity in Central America. P. Natl. Acad. Sci. USA 109, 8839-8844 (2012).

7. Myers, N. Threatened biotas: "Hot spots" in tropical forests. Environmentalist 8, 187-208 (1988).

8. Miller, K., Chang, E. \& Johnson, N. Defining Common Ground for the Mesoamerican Biological Corridor (World Resources Institute, 2001).

9. Morecroft, M. D. et al. Agricultural lands key to mitigation and adaptation - Response. Science 367, 518-519 (2020).

10. Fischer, J. et al. Conservation: limits of land sparing. Science 334(6056), 593.

https://doi.org/10.1126/science.334.6056.593-a (2011).

11. Vidal, A., Kumar, C., Zinngrebe, Y., Dobie, P., \& Gassner, A. Trees on farms as a nature-based solution for biodiversity conservation in agricultural landscapes (World Agroforestry/ICRAF, 2020).

12. Kremen, C. \& Merenlender, A. M. Landscapes that work for biodiversity and people. Science 362(6412). https://doi.org/10.1126/science.aau6020 (2018).

13. Vilchez, S. et al. Consistency in bird use of tree cover across tropical agricultural landscapes. Ecol. Appl. 24(1), 158-16 (2014).

14. Zermeño-Hernández, I., Pingarroni, A. \& Martínez-Ramos, M. Agricultural land-use diversity and forest regeneration potential in human-modified tropical landscapes. Agr. Ecosyst. Environ. 230, 210-22 (2016).

15. Shaver, I. et al. Coupled social and ecological outcomes of agricultural intensification in Costa Rica and the future of biodiversity conservation in tropical agricultural regions. Global Environ. Chang. 32, 7486 (2015).

16. Estrada-Carmona, N., Martínez-Salinas, A., DeClerck, F. A. J., Vílchez-Mendoza, S. \& Garbach, K. Managing the farmscape for connectivity increases conservation value for tropical bird species with different forest-dependencies. J. Environ. Manage. 250, 109504.

https://doi.org/10.1016/j.jenvman.2019.109504 (2019). 
17. Vandermeer, J. \& Perfecto, I. The agroecosystem: A need for the conservation biologist's lens. Conserv. Biol. 11, 591-592 (1997).

18. Pardon, P. et al. Trees increase soil organic carbon and nutrient availability in temperate agroforestry systems. Agr. Ecosyst. Environ. 247, 98-111 (2017).

19. Nair, P. R. The coming of age of agroforestry. J Sci. Food Agr. 87, 1613-1619 (2007).

20. Chatterjee, N., Nair, P. K. R., Chakraborty, S. \& Nair, V. D. Changes in soil carbon stocks across the Forest-Agroforest-Agriculture/Pasture continuum in various agroecological regions: A meta-analysis. Agr. Ecosyst. Environ. 266, 55-67 (2018).

21. Toledo-Hernández, M., Wanger, T. C. \& Tscharntke, T. Neglected pollinators: Can enhanced pollination services improve cocoa yields? A review. Agr. Ecosyst. Environ. 247, 137-148 (2017).

22. Pumariño, L. et al. Effects of agroforestry on pest, disease and weed control: A meta-analysis. Basic Appl. Ecol. 16, 573-582 (2015)

23. Tscharntke, T. et al. Multifunctional shade-tree management in tropical agroforestry landscapes - a review. J. Appl. Ecol. 48, 619-629 (2011).

24. Martínez-Fonseca, J. G., Chávez-Velásquez, M., Williams-Guillen, K. \& Chambers, C. L. Bats use live fences to move between tropical dry forest remnants. Biotropica 52, 5-10. https://doi.org/10.1111/btp.12751 (2020).

25. Prevedello, J. A., Almeida-Gomes, M. \& Lindenmayer, D. B. The importance of scattered trees for biodiversity conservation: A global meta-analysis. J. Appl. Ecol. 55, 205-214. https://doi.org/10.1111/1365-2664.12943 (2018).

26. Godinot, F., Somarriba, E., Finegan, B. \& Delgado-Rodríguez, D. Secondary tropical dry forests are important to cattle ranchers in Northwestern Costa Rica. Trop. J. Environ. Sci. 54(2), 20-50 (2020).

27. Harvey, C. A. et al. Patterns of animal diversity in different forms of tree cover agricultural landscapes. Ecol. Appl. 16(5), 1986-1999 (2006).

28. Gaoue, O. G. \& Ticktin, T. Patterns of harvesting foliage and bark from the multipurpose tree Khaya senegalensis in Benin: Variation across ecological regions and its impacts on population structure. Biol. Conserv. 137, $424-436$ (2007).

29. Mayfield, M. M. \& Daily, G. C. Countryside biogeography of Neotropical herbaceous and shrubby plants. Ecol. Appl. 15, 423-439 (2005).

30. Daily, G. C., Ceballos, G., Pacheco, J., Suzán, G. \& Sánchez-Azofeifa, A. Countryside biogeography of neotropical mammals: Conservation opportunities in agricultural landscapes of Costa Rica. Conserv. Biol. 
$17,1814-1826(2003)$.

31. Sánchez D., Harvey, C. A., Grijalva, A., Medina, A., Vílchez, S. \& Hernández, BI. Diversidad, composición y estructura de la vegetación en un agropaisaje ganadero en Matiguás, Nicaragua. Rev. Biol. Trop. 53(34), 387-414 (2005).

32. Sekercioglu, C. H., Loarie S. R., Oviedo Brenes F., Ehrlich, P. R. \& Daily G. C. Persistence of forest birds in the Costa Rican agricultural countryside. Conserv. Biol. 21, 482-494 (2007).

33. Wallace, G. N., Barborak, J., \& MacFarland, C. G. Land-use planning and regulation in and around protected areas: A study of best practices and capacity building needs in Mexico and Central America. Natureza y Conservaçao 3, 147-167 (2005).

34. Rozendaal, D. M. A. et al. Biodiversity recovery of Neotropical secondary forests. Sci. Adv. 5(30), eaau3114. https://doi.org/10.1126/sciadv.aau3114 (2019).

35. Ngo Bieng M. A. et al. Relevance of secondary tropical forest for landscape restoration. Forest Ecol. Manag. 493, 119265 (2021).

36. Souza Oliveira M. et al. Biomass of timber species in Central American secondary forests: Towards climate change mitigation through sustainable timber harvesting. Forest Ecol. Manag. 496, 119439. https://doi.org/10.1016/j.foreco.2021.119439 (2021).

37. Harvey, C. A. et al. Conservation value of dispersed tree cover threatened by pasture management. Forest Ecol. Manag. 261(10), 1664-1674 (2011).

38. Suding, K. N. Toward an Era of Restoration in Ecology: Successes, Failures, and Opportunities Ahead. Annu. Rev. Ecol. Evol. S. 42, 465-487 (2011).

39. Moguel, P. \& Toledo, V. Biodiversity conservation in traditional coffee systems of Mexico. Conserv. Biol., 13(1), 11-21 (1999).

40. Harrison, R. D., Harrison, S., Laumonier, Y., Somarriba, E. \& Suber, M. Biodiversity Monitoring for Agricultural Landscapes. A protocol using biodiversity metrics to monitor agricultural sustainability under Aichi Target 7 (World Agroforestry/ICRAF, 2019).

41. Heck, K. L., van Belle, G. \& Simberloff, D. Explicit calculation of the rarefaction diversity measurement and the determination of sufficient sample size. Ecology 56, 1459-1461 (1975).

42. Magurran, A. E. Measuring Biological Diversity (Blackwell, 2004).

43. Chao, A. et al. Rarefaction and extrapolation with Hill numbers: A framework for sampling and estimation in species diversity studies. Ecol. Monogr. 84, 45-67 (2014). 
44. Jost, L. Partitioning diversity into independent alpha and beta components. Ecology, 88(10) 24272439 (2007).

45. Gotelli, N. J. \& Colwell, R. K. Quantifying biodiversity: procedures and pitfalls in the measurement and comparison of species richness. Ecol. Lett. 4, 379-391 (2001).

46. Zuur, A., leno, E. N., Walker, N., Saveliev, A. A. \& Smith, G. M. Mixed effects models and extensions in ecology with $R$ (Springer, 2009).

47. R Core Team. R: A language and environment for statistical computing. https://www.R-project.org/ (R Foundation, 2021).

48. Oksanen, J. et al. Vegan: Community Ecology Package. R package version 2.5-7. https://CRAN.Rproject.org/package=vegan $(2020)$.

49. Hsieh, T. C., Ma, K. H. \& Chao, A. iNEXT: iNterpolation and EXTrapolation for species diversity. R package version 2.0.20. https://cran.r-project.org/web/packages/iNEXT/index.html (2020).

50. Venables, W. N. and Ripley, B. D. Modern Applied Statistics with S(Springer, 2002).

51. Wickham, H. ggplot2: Elegant Graphics for Data Analysis (Springer, 2016).

52. Auguie, B. gridExtra: Miscellaneous Functions for "Grid" Graphics. R package version 2.3. https://CRAN.R-project.org/package=gridExtra (2017).

\section{Figures}




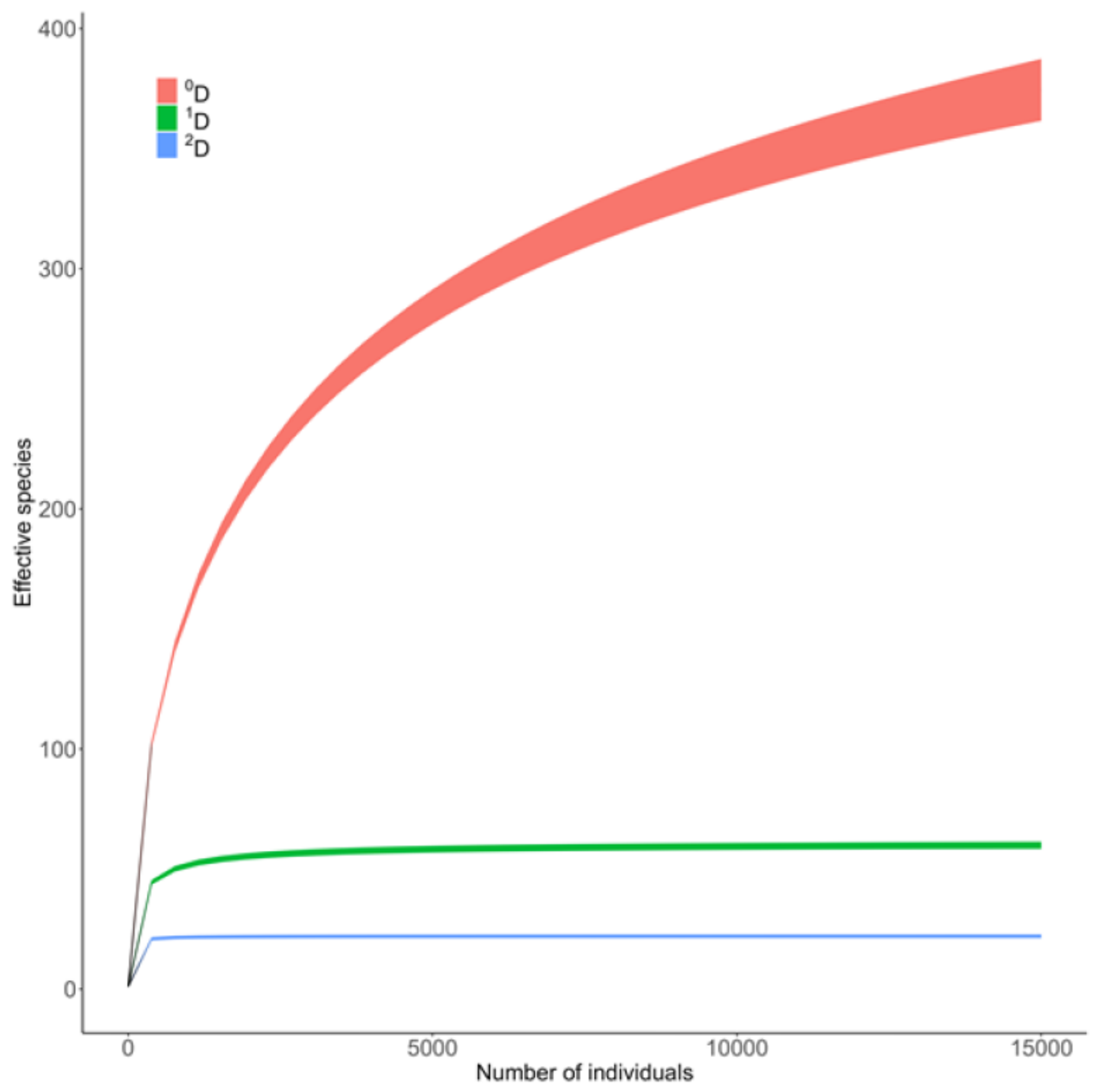

Figure 1

Accumulation curve of effective species for Hill numbers. The curve is based on the Hill numbers of order ${ }^{0} \mathrm{D}$ (total effective number of species), ${ }^{1} \mathrm{D}$ (effective number of common species) and ${ }^{2} \mathrm{D}$ (effective number of dominant species). Colored areas represent $95 \%$ confidence intervals. 


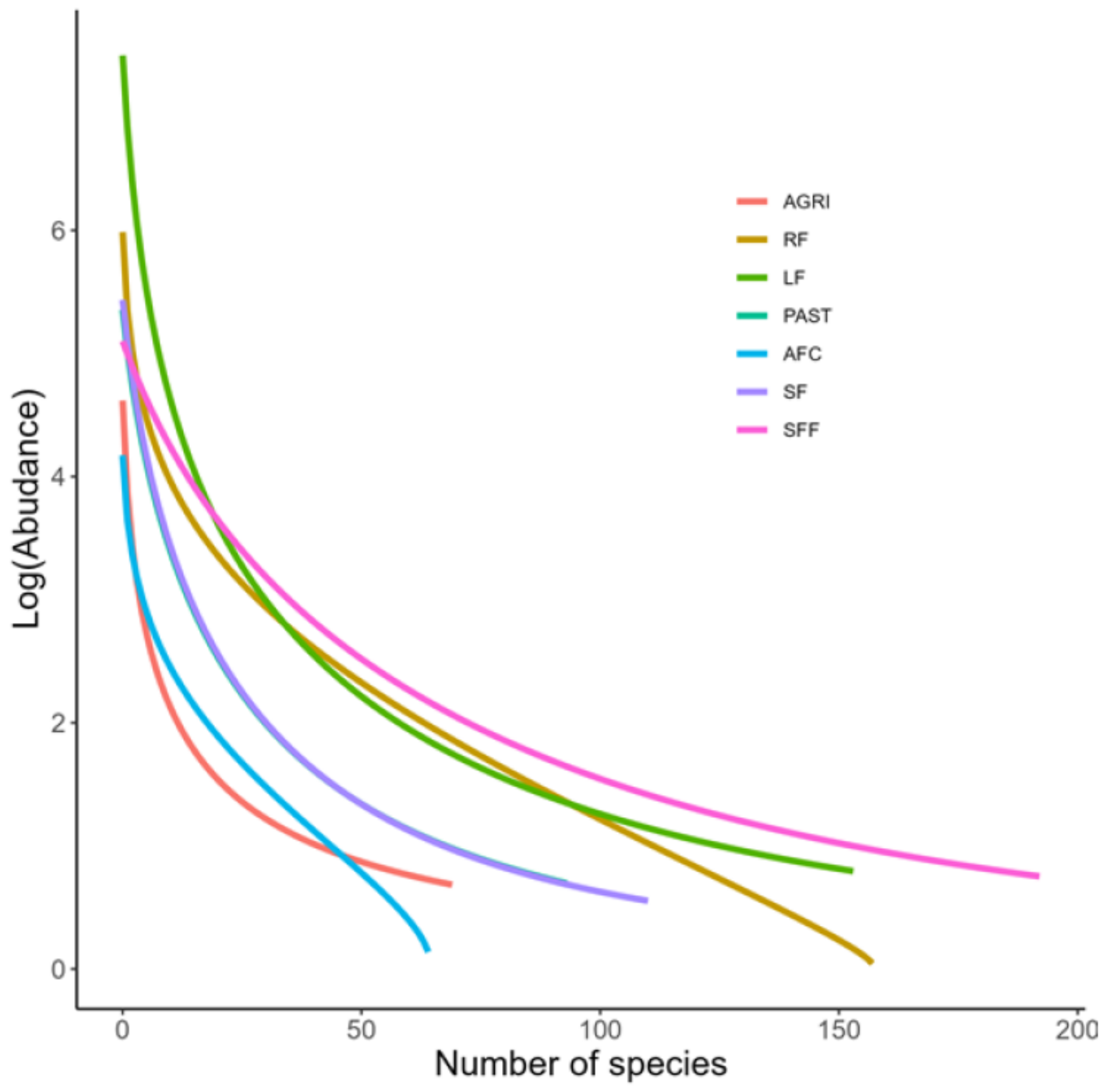

Figure 2

Species rank-abundance curves for each land use. The curves for the secondary forest (SF), secondary forest fragments (SFF), live fences (LF) and pasture (PAST) fit the Zipf-Mandelbrot model. The curves for riparian forest (RF) and agroforestry coffee (AFC) fit the Lognormal model, while the curve for agriculture (AGRI) fits the Zipf model. 

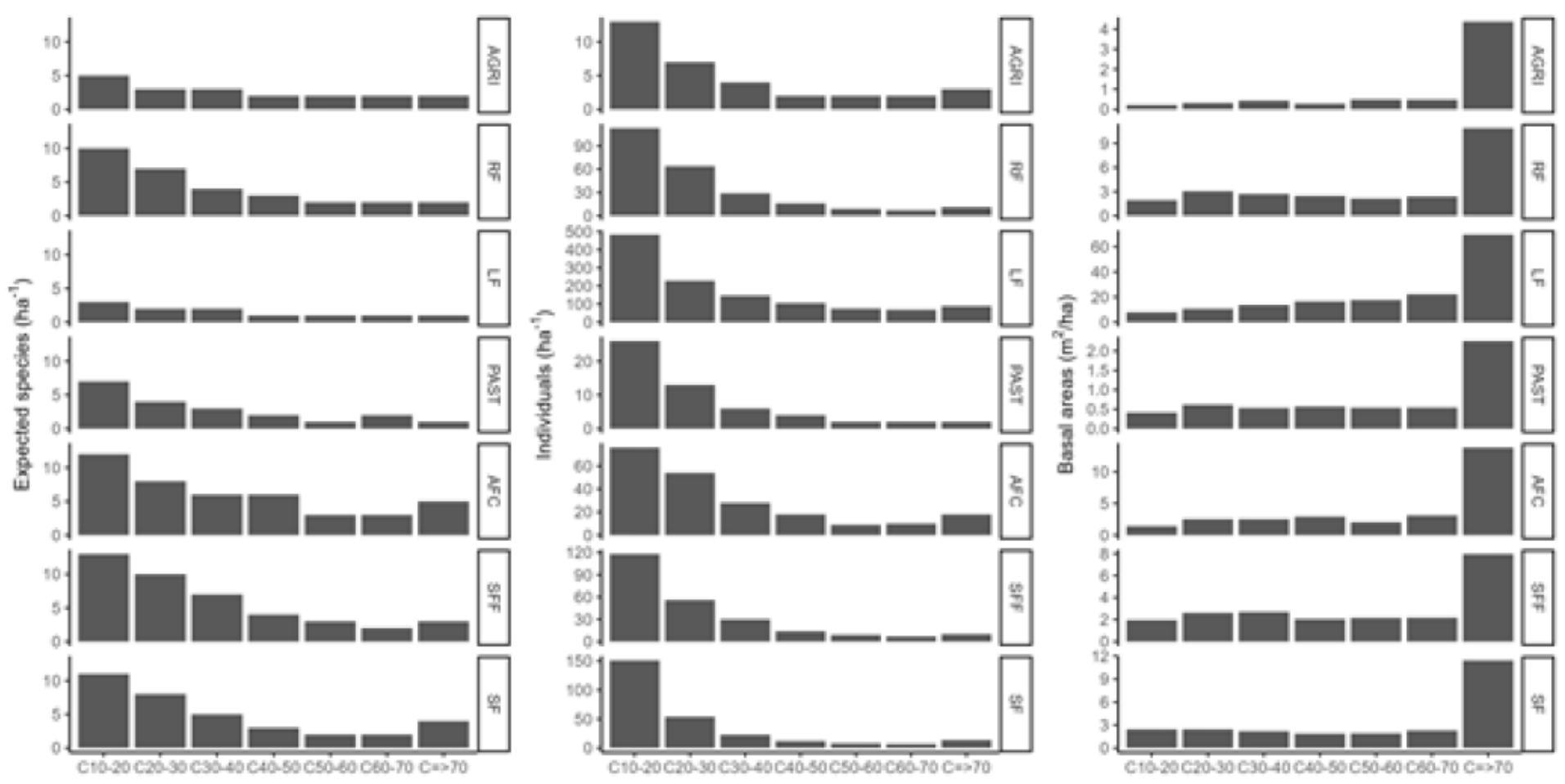

Diametric classes

Figure 3

Diameter class distributions for species (first column), tree density (second column) and basal areas (third column) for each land use. The three metrics are standardized per hectare. The different land uses are secondary forest (SF), secondary forest fragment (SFF), agroforestry coffee (AFC), agriculture (AGRI) and pastures (PAST), live fences (LF) and riparian forest (RF). 


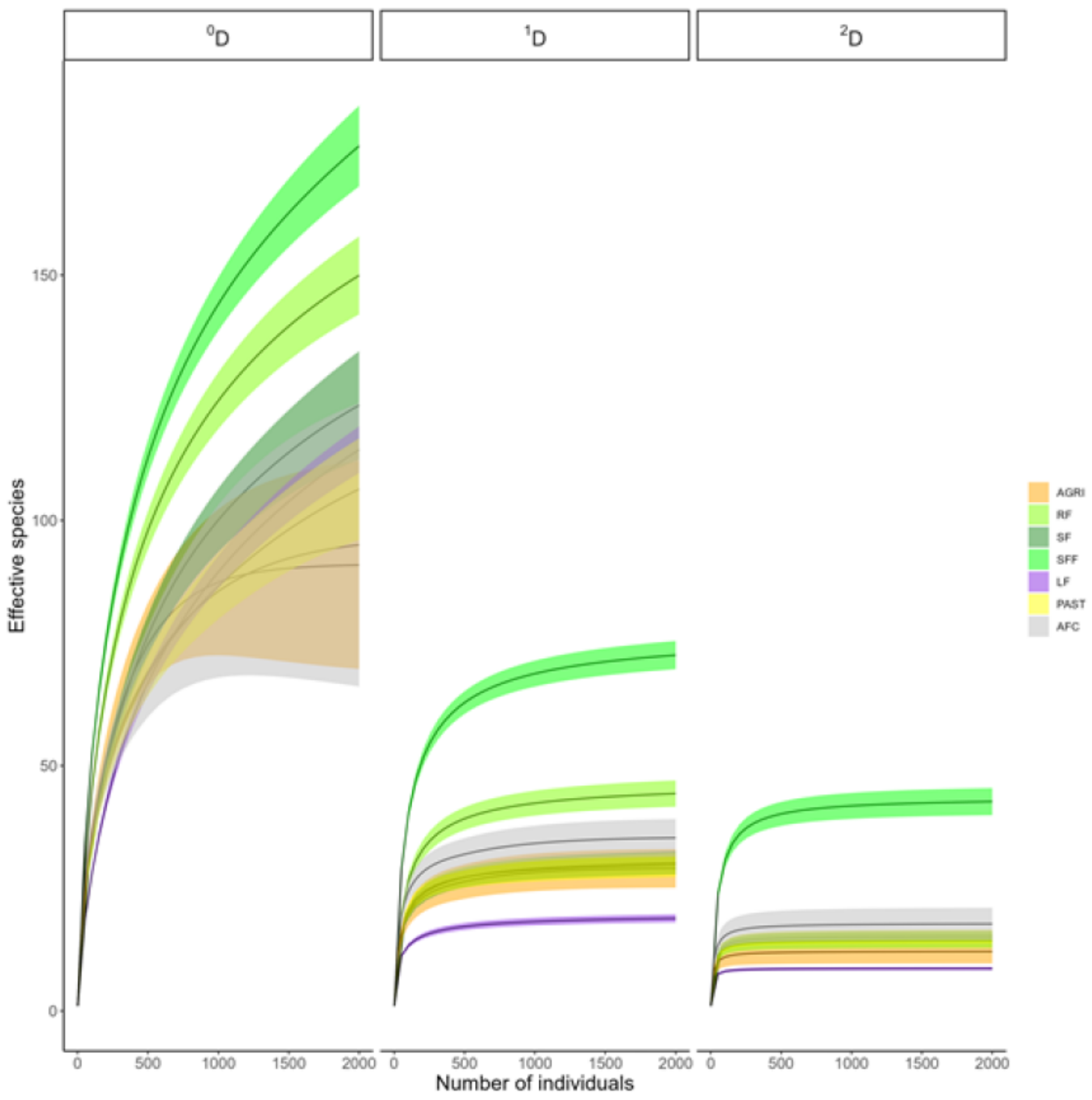

Figure 4

Accumulation curves (interpolation-extrapolation) of effective species for each land use in Catacamas. The curve is based on the Hill numbers of order ${ }^{0} \mathrm{D}$ (total effective number of species), ${ }^{1} \mathrm{D}$ (effective number of common species) and ${ }^{2} \mathrm{D}$ (effective number of dominant species). Colored areas represent a $95 \%$ confidence interval. 


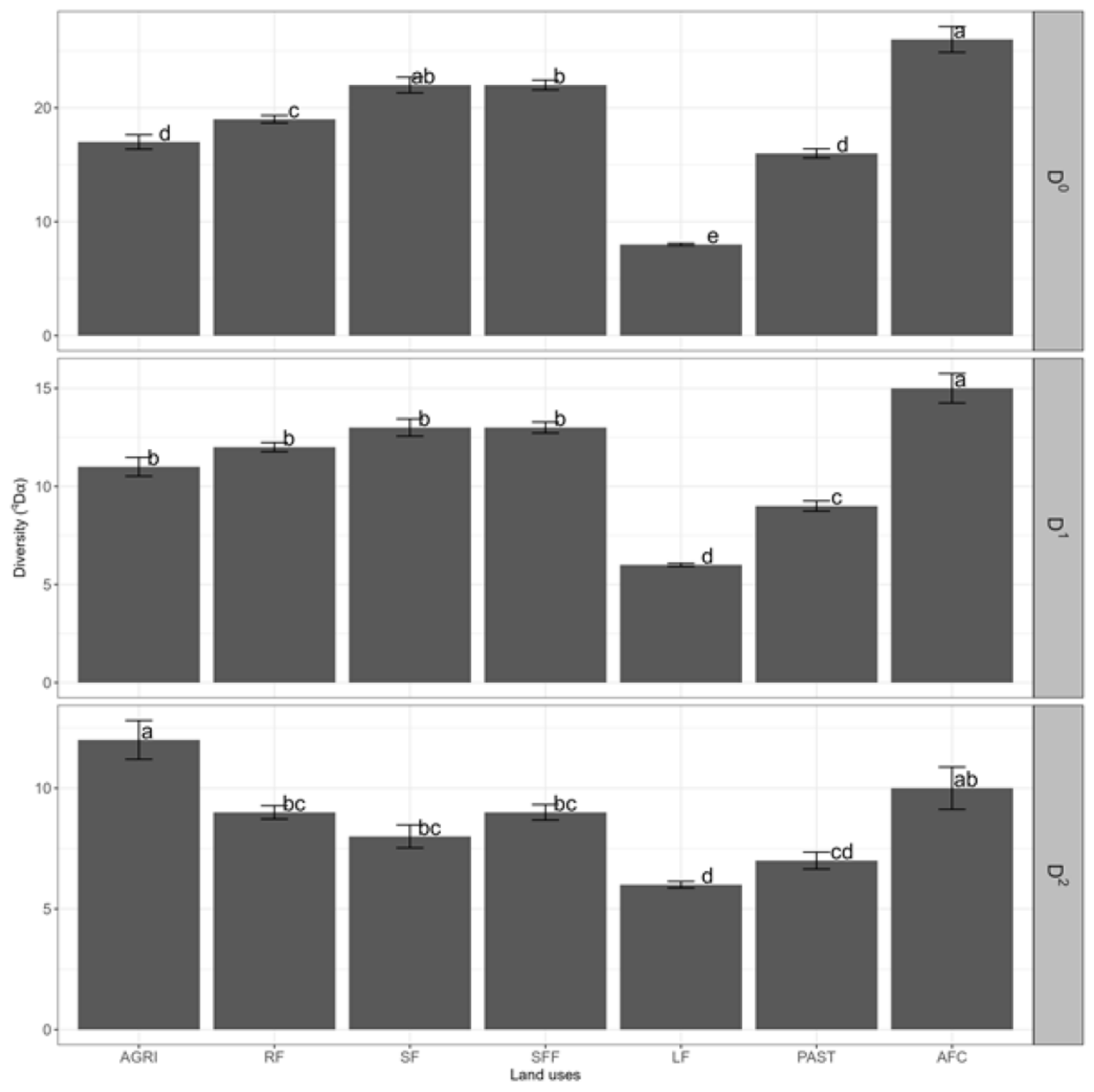

Figure 5

Alpha diversity averages and errors associated with each land use, according to the effective number of species based on Hill numbers of order ${ }^{0} \mathrm{D}$ : (total effective number of species), ${ }^{1} \mathrm{D}$ (effective number of common species) and ${ }^{2} D$ (effective number of dominant species). The different letters indicate significant differences with $a=0.05$. 


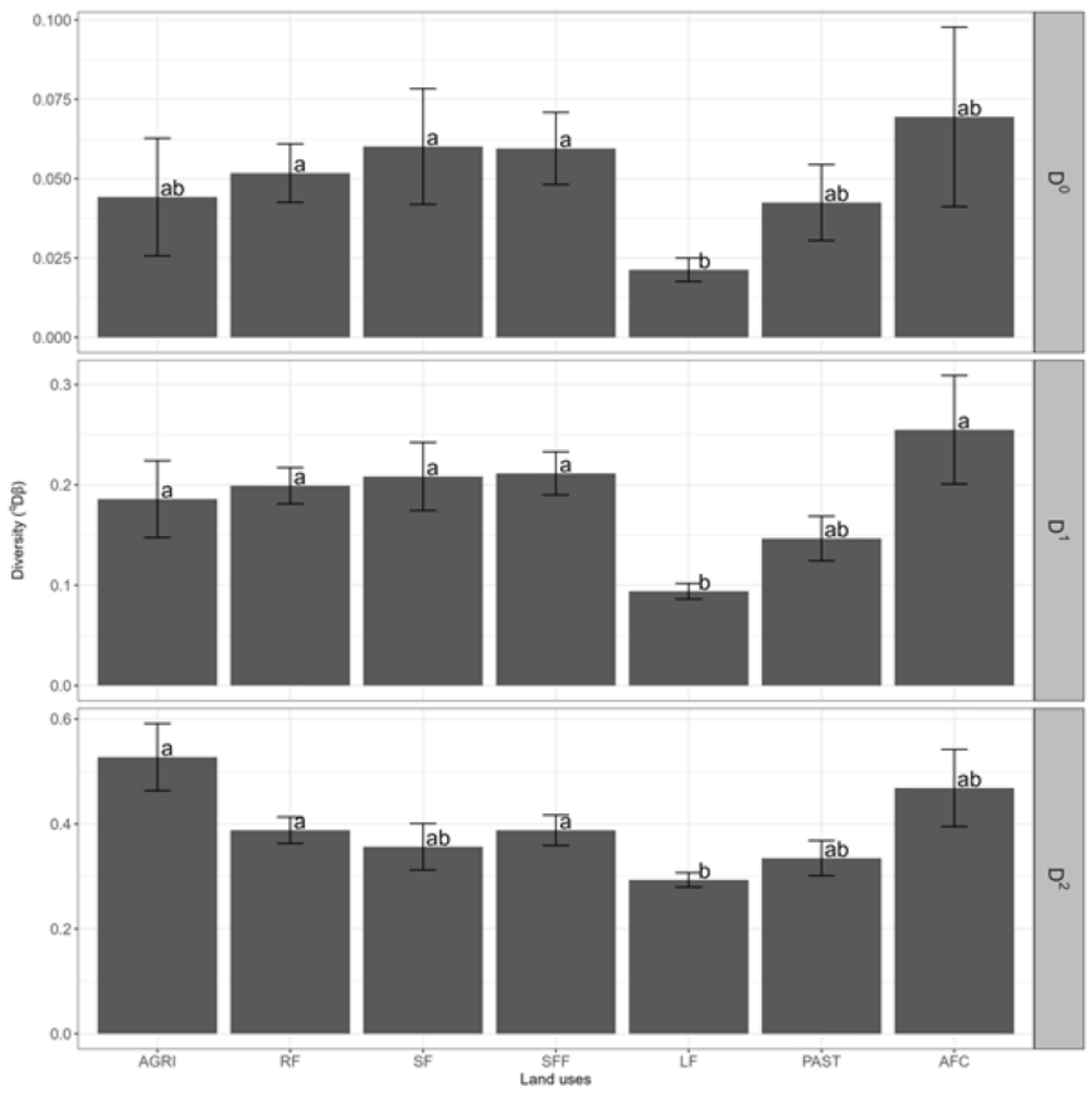

Figure 6

Beta diversity as a specific measure of dissimilarity compared to the total diversity of the landscape. Means and errors associated with each land use, according to the proportion of different species based on the Hill numbers of order ${ }^{0} D$ (total effective number of species), ${ }^{1} D$ (effective number of common species) and ${ }^{2} D$ (effective number of dominant species). The different letters indicate significant differences with $a=0.05$. 


\section{Figure 7}

Catacamas landscape $(25 \mathrm{~km} \times 25 \mathrm{~km})$ with ten $5 \times 5 \mathrm{~km}$ sampling quadrats.

\section{Supplementary Files}

This is a list of supplementary files associated with this preprint. Click to download.

- Supplementarylnformation.pdf 